\title{
Differentials in Usage of Information and Communication Devices Among Extension Agents: A Study on North-Western Zone, Nigeria
}

\author{
Fadiji Taiye Oduntan ${ }^{1}$, Sennuga Samson Olayemi, ${ }^{2,}$, Angba Augustine Oko ${ }^{3}$ \\ ${ }^{1}$ Department of Agricultural Extension and Rural Sociology, Faculty of Agriculture, University of Abuja, Abuja, Nigeria \\ ${ }^{2}$ School of Agriculture, Food and Environment, Royal Agricultural University, Stroud Road, Cirencester, Gloucester, GL7 6JS, United \\ Kingdom \\ ${ }^{3}$ Department of Agricultural Extension and Rural Sociology, University of Calabar, Calabar, Nigeria
}

\author{
Email address: \\ dr.yemisennuga@yahoo.co.uk (S. S. Olayemi) \\ *Corresponding author
}

\section{To cite this article:}

Fadiji Taiye Oduntan, Sennuga Samson Olayemi, Angba Augustine Oko. Differentials in Usage of Information and Communication Devices among Extension Agents: A Study on North -Western Zone, Nigeria. American Journal of Agriculture and Forestry.

Vol. 9, No. 1, 2021, pp. 42-48. doi: 10.11648/j.ajaf.20210901.17

Received: January 18, 2021; Accepted: January 25, 2021; Published: February 10, 2021

\begin{abstract}
The awareness and the extent of usage of Information and Communication Technology (ICT) components by Village Extension Agents (VEAs), in three selected States Agricultural Development Projects (ADPs) of Nigeria, were investigated. Two hundred and four (204) VEAs were sampled as respondents for the study. With aid of simple statistical tools (average, cumulative and percentages), and the analysis of the results indicate that the level of awareness of ICTs among the respondents (VEAs) was quite high especially on radio (99\%), GSM phones (96\%); and television (93\%). On the contrary, the level of awareness was low on fax (68\%) and Personal Digital Assistant (PDAs) (69\%). It was also noted that the following devices were highly used by the respondents; GSM phones, radio, cassette recorder, television, CD/DVD player and VHS Video player. Unfortunately, the respondents recorded least ICT usage on fax and PDAs. It was recommended that both awareness and usage of available ICT formats should be intensified among VEAs so as to optimize their usage in the effective performance on the job.
\end{abstract}

Keywords: Agriculture, Development, Extension Agents, Information, Communication

\section{Introduction}

Information and Communication Technology (ICT) components/devices available include the following: Multimedia systems (VCDs, DVDs, VHS, Over-head projectors), Telephones (Land-lines and Mobile phones), Internet (Emailing, Web-browsing, telephoning), Radio, Television, Computers and Personal Digital Assistants (PDAs). Others include: Cable Satellite, online Newspapers, e-Books, journals, tablet systems (e. g. ipads, Galaxy Tabs) and smart phones, Media Players (MP 2, 3 \& 4), Geographic Information System (GIS) and Geographic Position System (GPS). In a wider sense, it includes such tools as: Internet, elearning technologies, CD ROMs, CDs, DVDs, etc).

The problems of illiteracy and ignorance coupled with inadequate flow of information are obvious in many countries. The importance of information on research and development cannot be over-emphasized with its attendant usefulness to promote literacy and knowledge. Indeed, the usefulness of information and credibility of information source have been found to be positively and significantly related to adoption of improved cassava production technologies [12].

In many countries nowadays, emphasis is being placed on the need to use ICT devices/media to exchange information with the stakeholders such as: farmers, extension agents, researchers, administrators, policy-planners, marketers, cooperatives, agro-processors, Non-Governmental organizations (NGOs). [18] stated that ICT, apart from being user-friendly, easy to access, cost effective and well- 
protected from unauthorized accesses, also serves the following purposes: Record text, drawings, photographs, audio, video, process descriptions, and other information in digital formats; produce exact duplicates of such information at significantly lower cost; transfer information and knowledge rapidly over large distances through communications networks; develop standardized algorithms to large quantities of information relatively rapidly; and achieve greater interactivity in communicating, evaluating, producing and sharing useful information and knowledge.

The limitations and constraints found in the traditional and formal communication channels have made ICT application more relevant [21]. Consequently, because of its wide application in scope and coverage, a more satisfactory and useful mechanism for innovation in communication in agricultural context is desirable [16]. This has thus brought about the introduction of ICT as an innovation in agricultural development.

For instance, Leeuwis and Van den Ban documented an extensive work on communication for innovation looking at the changing perspectives and the organizational and interorganizational issues involved [10]. Specific to the media methods, and process management, the work outlined issues related to farm management, pre-defined issues, exploration and training. Their work went further to examine methods related to information provision with discussion on written and computer-based search and access facilities as well as information-needs assessment. Contreras examined the impact of communication on modernity thus generating a thesis that communication has not played as important role in rural development in developing countries because of a series of structural constraints under which it has operated and, of course, will probably continue to operate [7].

Rogers and Burdges Defined social change as: "the process by which alteration occurs in the structure and function of a social system" [17]. Examples of social change, in their view, include issues such as; national revolution, the invention of a new manufacturing technique, the founding of a village improvement council, and the adoption of birth control methods by a family. Explaining further, on the process of change, they presented it in three sequential steps, namely; (1) Invention, (2) Diffusion, and (3) Consequences. Their definitions of each of these are as follows:

Invention is the process by which new ideas are created or developed. Diffusion is the process by which these new ideas are communicated to the members of a social system. Consequences are the result of the adoption or rejection of the innovation. Change occurs when a new idea has an effect.

Jibowo Described Social change as when viewed within the context of a social system, it is the alteration in the values, norms, social roles, habits, obligations of people, or change in life-style, life goals, chances, environment, or in the composition or organization of their society [9]. Eisenstadt greatly contributed to the theory of social change by giving a focus on the functionists' perspective on structural change and modernization. He argued that every social system has a tendency for change [8]. The development of the theory was traced to Europe, which had owed much to its various traditions, city-state, imperial and feudal, and more, to the development of commerce and secularism. Reports had it that Protestants Reformation played a crucial role in the eventual restructuring of Europe in the fifteen century [14].

In the Functionalist perspectives, Social Change can occur at both micro level and macro level. At micro-level, it involves the group and people within one's immediate environment while at macro-level, it involves the economic, political and educational systems.

There is the drive for change and development, and this is being promoted through the instrumentality of ICT, including Nigeria. With the gradual exposure of the rural areas to the ICT, VEAs, as agents of change, are in good position to exploit the available technologies in their trainings and information exchange. For a meaningful extension service delivery and innovation adoption to be achieved, the deployment and application of ICT would go a long way in improving agricultural practices, production, productivity just like in the advanced countries that have used ICT appropriately. This study presents an examination of the emerging trend, the use of modern technologies and devices in information and communication by the extension agents. Thus, change is envisaged to realize improvement and efficiency in the work relation and job performance of the extension workers.

Objectives of the study:

The following are the two objectives that guided us in carrying out the study:

1) To identify the socio-economic characteristics of the VEAs in the study area.

2) To investigate the level of awareness of ICT by VEAs in the study area, and

3) To determine the extent of ICT usage by VEAs in their work, in the study area.

\section{Methodology}

A structured questionnaire was designed to adequately elicit information needed for the study. A multi-stage sampling technique was used for the study. The first stage was identification of the study area and the population. The population for the study focused on the VEAs in the NorthWest Geopolitical Zone of Nigeria comprising seven States, namely: Kaduna, Kano, Katsina, Kebbi, Jigawa, Sokoto and Zamfara States). The second stage involved the use of purposive sampling technique. Thus, Out of seven (7) states in the North-WestGeopolitical Zone, three States' ADPs (Kaduna, Kano and Kebbi States) were purposively chosen for this study taking into cognizance the need to give geographical representation and coverage of the Zone (i.e. three states chosen out of seven states constituted $42 \%$ ).

From each State ADP, in the third stage of the technique used, involved the use of random sampling technique. Invariably, a list of the VEAs was obtained for the study; out of the VEAs' population $(1,018)$ in the zone, $20 \%$ (i.e. 204 
VEAs) was randomly selected as respondents. The breakdown of respondents was 111, 48 and 45 from Kano,

Kaduna and Kebbi States' ADPs respectively (Table 1).

Table 1. The population and sample sizes of respondents (the VEAs) for the study.

\begin{tabular}{llll}
\hline S/No & State ADPs & Numberof the VEAs (Sample frame) & Sample size (20\%) \\
1 & Kebbi State ADP (KARDA) & 226 & 45 \\
2 & Kaduna State ADP (KADP) & 241 & 48 \\
3 & Kano State ADP (KNARDA) & 551 & 111 \\
& Total & 1018 & 204 \\
\hline
\end{tabular}

The threes selected states where the study was carried out are shown in Figure 1.
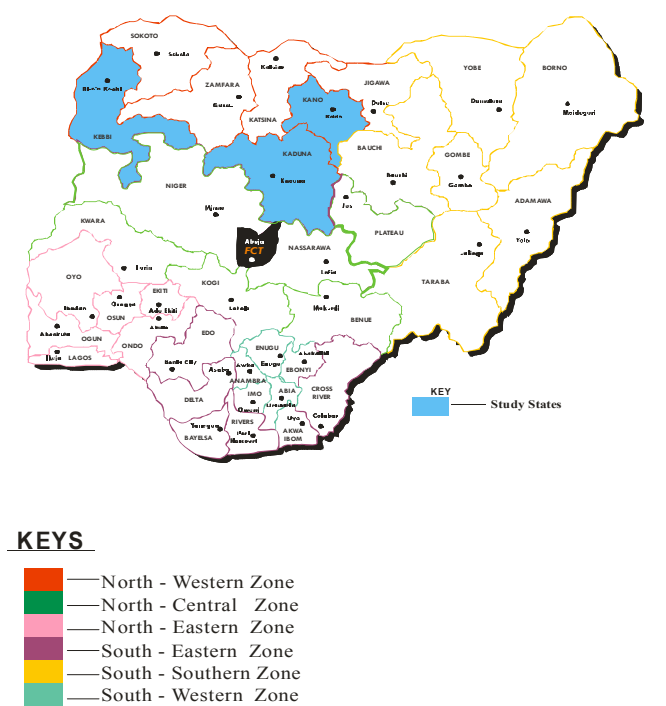

Figure 1. Map of Nigeria showing the three States where the study covered.

\section{Results and Discussion}

Socio-economic characteristics of the Village Extension Agents (VEAs).

Majority (80\%) of the respondents were between 40 - 49 years old (table 2). An overwhelming number $(80 \%)$ of the extension agents were males, about $80 \%$ were married and $83 \%$ were from household size of 10 or less members. Most (44\%) of them had HND, followed by those (34\%) who had OND - indicating that they are literate and by virtue of their education, could appreciate ICT's relevance and usefulness.

Specific to their working experience, $51 \%$ of them had 19 years and above, $12 \%$ had $15-18$ years working experience thus indicating they were well experienced in their jobs and this gave them advantage of appreciating ICT's role; majority of VEAs (32\%) had extension visits of 1-5 per month which shows that they were actively involved in carrying out their function of making contacts with farmers.

On social participation, $38 \%$ of the respondents belonged to only 1 group, and on their linguistic competence, majority (63\%) spoke 2 languages frequently - thus indicating their high linguistic competence. On their income, most (48\%) were in the income range ( $\$ 301,000.00-400,999.00)$. Their income level shows that they were low earners civil servants which may not make them comfortable at work. The awareness level on ICT components of the respondents show that the largest percentage (14\%) were aware of all the selected 14 ICT components, thereby giving the impression that their awareness level was generally high. Specific to their Accessibility to ICT, results show that the largest percentage of them (45\%) had access to 5-8 ICT components.

The awareness of ICT by VEAs

Radio

Table 3 shows the level of the respondents' awareness of radio was highly impressive as majority of them (99\%) were aware while just a negligible number of the VEAs (1\%) claimed to be unaware. This lays credence to the fact that radio is a dominant source of information, and indeed a vital tool in agricultural information dissemination in rural areas. This situation is a confirmation of earlier reports by $[1,15$, $19,20]$. Thus, radio was a veritable tool for both information dissemination and source of information which could assist in extension delivery and excellent job performance.

GSM/cell Phones

With respect to awareness of GSM/cell phones, in Table 3, results of analysis show that the majority (98\%) of the respondents indicated they were aware of the GSM phones while a negligible proportion (3\%) of them indicated they were not aware. This shows that the awareness of the respondents on Mobile phone is quite high [4].

Television (TV) set

The results in Table 3 show that majority (93\%) of the respondents were aware of the existence of TV set, while a few $(7 \%)$ of them were unaware of it. This shows that TV set is popular among the respondents. This is quite impressive considering the importance of television set in the dissemination of agricultural information today.

Cassette recorder

The result in Table 3 further shows that the level of the respondents' awareness of Cassette recorder was impressive as the majority ( $87 \%$ ) of them were aware while only $13 \%$ of the VEAs were unaware. This situation could be attributable to the wide and extensive nature of its use coupled with low cost of purchase.

Compact Disk (CD)/Digital Video Disk (DVD) player

With reference to awareness of VCD/DVD players by the respondents, the findings on Table 3 indicate that majority of the respondents $(79 \%)$ were aware of $\mathrm{VCD} / \mathrm{DVD}$ players and $21 \%$ of them were unaware. By implication, the respondents were highly aware of VCD/DVD players. This might not be unconnected with the gradual dependence on CDs and DVDs as a means of data storage and retrieval in the informationdriven world of today.

Video Home System (VHS) Player 
Similarly, on awareness of VHS player, in Table 3 , it is shown that a significant proportion of the respondents (77\%) were aware of VHS video players while a few of them $(23 \%)$ were unaware. This might be due to the popularity it enjoyed for many decades by reason of its constant use in Nigeria.

Camera

In Table 3, with respect to camera awareness, it was discovered that majority of the respondents (75\%) were aware of the camera while the remaining $25 \%$ of them were unaware of it. The high awareness level might be attributable to the growing marketing and use of camera in Nigeria.

Cinema

The results on Table 3 indicate that awareness of Cinema among the respondents was high with $68 \%$ of them while only $32 \%$ of the VEAs were not aware. This development might be due to the gradual phasing out of and less reliance on cinema in extension information delivery to farmers with its attendant problems of high cost and inaccessibility.

Computer

The experience of the respondents on awareness of computer, in Table 3, shows that the level was generally a little above average as $60 \%$ of them while $40 \%$ of them were unaware. This situation could not be far from the cost of purchase, lack of purchasing power and accessibility to computers, and more importantly, because VEAs reside mostly in rural areas.

Overhead projector

On the awareness of overhead projector by the respondents, results in Table 3 indicate that $55 \%$ of them were aware of it while the remaining $45 \%$ of them were unaware. This might be attributable to the cumbersome nature of its components and the technical expertise required to handle it.

Landline phones

The findings on Table 3 indicate that awareness of landline phones (fixed phones) among the respondents was 54\% of them while $46 \%$ of them were not aware. By implication, the respondents' level of awareness of fixed phones was low. This might not be unconnected with the gradual disappearance and usage of fixed/landline phones in Nigeria which is being fast replaced by GSM/cell phones.

Internet (E-mailing)

In Table 3, on the awareness of respondents on internet (emailing), a little above half of them (53\%) indicated they were aware of Internet (e-mailing) while the remainder of them $(47 \%)$ were unaware. This situation could be attributed to its low accessibility in the rural areas.

Fax

The respondents' experience with awareness of fax in Table 3 shows the vast majority of the VEAs $(68 \%)$ were grossly unaware, while just $32 \%$ of them were aware. This situation could not be far from reason connected with the rarity of fax usage, its sophistication and special nature of communication it is used for.

Personal Digital Assistants (PDAs)

With particular reference to awareness of the respondents on PDAs, the results in Table 3 show the level was generally low with only $31 \%$ of them having the awareness while the vast majority of them $(69 \%)$ of them were not aware. This situation could be due to the nature of PDAs' sophistication, complication and cost.

Table 2. Distribution of respondents based on their socio-economic characteristics ( $n=204)$.

\begin{tabular}{|c|c|c|c|}
\hline Socio-economic characteristics of the respondents & Frequency & Percentage (\%) & Mean \\
\hline \multicolumn{4}{|l|}{ Age (years) } \\
\hline $20-29$ & 21 & 10.3 & \\
\hline $30-39$ & 40 & 19.6 & \\
\hline $40-49$ & 120 & 58.8 & 40.83 \\
\hline $50-59$ & 23 & 11.3 & \\
\hline \multicolumn{4}{|l|}{ Gender (Sex) } \\
\hline Male & 182 & 80.2 & 1.11 \\
\hline Female & 22 & 9.7 & \\
\hline \multicolumn{4}{|l|}{ Household size } \\
\hline $1-10$ & 169 & 82.9 & \\
\hline $11-20$ & 32 & 15.7 & 6.76 \\
\hline $21-40$ & 3 & 1.5 & \\
\hline \multicolumn{4}{|l|}{ Marital status } \\
\hline Single & 25 & 11.0 & \\
\hline Married & 179 & 78.9 & 1.88 \\
\hline \multicolumn{4}{|l|}{ Extension visits (No per month) } \\
\hline $0-5$ & 65 & 32 & \\
\hline $6-10$ & 33 & 16.2 & \\
\hline $11-15$ & 45 & 22.1 & \\
\hline $16-20$ & 46 & 22.6 & 5.42 \\
\hline $21-30$ & 12 & 5.9 & \\
\hline $31-45$ & 3 & 1.5 & \\
\hline \multicolumn{4}{|l|}{ Level of education (highest attainment) } \\
\hline Primary School & 2 & 0.9 & \\
\hline Secondary School & 19 & 8.4 & \\
\hline OND & 78 & 34.4 & \\
\hline HND & 100 & 44.4 & \\
\hline B. Sc. & 5 & 2.2 & \\
\hline
\end{tabular}


Table 3. Distribution of the respondents according to their level of awareness of ICT $(n=204)$.

\begin{tabular}{|c|c|c|c|c|c|}
\hline \multirow{3}{*}{ S/No } & \multirow{3}{*}{ ICT Component } & \multicolumn{4}{|c|}{ Level of awareness } \\
\hline & & \multicolumn{2}{|c|}{ Aware } & \multicolumn{2}{|c|}{ Not aware } \\
\hline & & $\mathbf{F}$ & $\%$ & $\mathbf{F}$ & $\%$ \\
\hline 1 & Radio & 202 & 99.0 & 2 & 1.0 \\
\hline 2 & GSM phones & 199 & 97.5 & 5 & 2.5 \\
\hline 3 & Television set & 190 & 93.1 & 14 & 6.9 \\
\hline 4 & Cassette recorder & 177 & 86.8 & 27 & 13.2 \\
\hline 5 & CD/DVD player & 161 & 78.9 & 43 & 21.1 \\
\hline 6 & VHS Video player & 157 & 77.0 & 47 & 23.0 \\
\hline 7 & Camera & 153 & 75.0 & 51 & 25.0 \\
\hline 8 & Cinema & 138 & 67.6 & 66 & 32.4 \\
\hline 9 & Computer & 123 & 60.3 & 81 & 39.7 \\
\hline 10 & Overhead projector & 113 & 55.4 & 91 & 44.6 \\
\hline 11 & Land line phones & 111 & 54.4 & 93 & 45.6 \\
\hline 12 & Internet (e-mailing) & 108 & 52.9 & 96 & 47.1 \\
\hline 13 & Fax & 66 & 32.4 & 138 & 67.6 \\
\hline 14 & Personal digital assistant (PDA) & 64 & 31.4 & 140 & 68.6 \\
\hline
\end{tabular}

The Extent of ICT usage by VEAs on their work GSM phones

The result in Table 4 shows the extent in percentage of VEAs' usage of GSM phones for their work. It indicates that $75 \%$ of the respondents used.

GSM phones very often, $17 \%$ often, $6 \%$ rarely and $2 \%$ not use it at all. This study therefore agrees with [4] who discovered that journalists have been assisted as GSM phone use has improved their work performance. Also, it concurs with Aderintoet al., (2008)'s report to the effect that 59\% of the respondents used telephone. It further confirms [3, 18] reported that ICT devices were owned and used by some agricultural extension and research organizations namely: computers, tele-fax, telephone, websites, E-mail, radio, television, and VCD/VCR thereby laying credence to the importance of these devices. Furthermore, it agrees with [5] that revealed the remarkable development in the use, throughout Africa, by women of ICT components such as mobile phones, CD-ROMs and internet.

Landline phones

With respect to usage of landline, results obtained in Table 4 shows that $6 \%$ of the VEAs used land-line phones very often, $21 \%$ often, $21 \%$ rarely and $53 \%$ not use it at all. Generally, the results show that land-line phones were poorly used by the respondents in their work. This might not be far from the fact that land-line phones were usually fixed and were already gradually being phased out as at the time of the investigation.

Television (TV) set

With reference to usage of television set, the result in Table 4 shows the respondents used television sets as follows: $32 \%$ of them used it very often, $24 \%$ often, $22 \%$ rarely and $23 \%$ of them used it not at all. This shows that television sets were moderately used the respondents in their work. Thus, this finding agrees with others that stressed the usage of ICT [1] and [3].

Cinema

With regard to the usage of cinema, Table 4 indicates that only $3 \%$ of the respondents used it very often, $19 \%$ often, $29 \%$ rarely and $49 \%$ of them did not use at all. Generally, this result shows that cinemas were poorly used by the respondents in their work.

$\mathrm{CD} / \mathrm{DVD}$ player

On the usage of CD/DVDs, results shown in Table 4 indicate that $16 \%$ of the respondents used it very often, $29 \%$ used it often, $22 \%$ used it rarely and $33 \%$ of them did not use it at all. This finding indicates a generally moderate usage of CD/DVD among the respondents.

VHS Video player

The result in Table 4 shows the extent in percentage of the respondents' usage of VHS Video players for their work. It indicates that $16 \%$ of the respondents used it very often, $27 \%$ often, $22 \%$ rarely and $36 \%$ of them did not use at all. This shows that VHS Video players were moderately used by VEAs in their work.

Camera

In considering the usage of camera, the result in Table 4 shows that $10 \%$ of the respondents used camera very often, $19 \%$ of them used it often, $37 \%$ used it rarely and $34 \%$ did not at all. This shows that cameras were not often used by the respondents in the performance of their job.

Internet (e-mailing)

Looking at the usage of Internet (e-mailing) by the respondents, the results in Table 4 show that only $2 \%$ of them used it very often, $10 \%$ often, $34 \%$ rarely and $53 \%$ did not use it at all. This shows that Internet (E-mailing) was used poorly by the respondents in the performance of their job. This was contrary to [6] that found on operation of electronic e-Government, an assessment of a Government based website, that majority of the respondents (40\%) agreed that phone contact, address contact, publications, link to other sites and data bases would help an ordinary citizen contact a Government agency. Also, 55\% of the respondents stated that the use of E-mail would help citizens contact Government officials and make use of information on websites.

Computer

On the use of computer by the respondents, the result in Table 4 shows that $5 \%$ of them used it very often, $14 \%$ used it often, $33 \%$ rarely and $48 \%$ did not at all. This shows that Computers were poorly used by the respondents in the 
performance of their job. However, this was contradicted by [2] who reported that $85 \%$ of the respondents in their study had access to computers while $15 \%$ did not have access.

Overhead projector

The result in Table 4 shows that $0.5 \%$ of the respondents used overhead projector very often, $7 \%$ often, $29 \%$ rarely and $63 \%$ not at all. This shows that overhead projectors were poorly used by the respondents in the performance of their job.

Fax

The result in Table 4 on the use of Fax by the respondents shows that $2 \%$ used it very often, $2 \%$ used it often, $12 \%$ used it rarely and majority (85\%) of them did not at all. This shows that Fax was poorly used by the respondents in the performance of their job.

Cassette recorder

On the use of Cassette recorder, the result in Table 4 shows that only $32 \%$ of the respondents used it very often, $28 \%$ often, $15 \%$ rarely and $25 \%$ not at all. This shows that cassette recorders were moderately used by the respondents in their work. Thus, this finding agrees with [11] that reported on a typical ICT usage project involving extension workers and farmers in the Pacific in terms of ability to produce DVDs, printed guides, radio and TV programmes in strengthening rural economies.

Personal Digital Assistants (PDAs)

With reference to PDAs, the result in Table 4 shows that $5 \%$ of the respondents used it very often, $8 \%$ often, $17 \%$ rarely and $70 \%$ not at all. Generally, this result shows that PDAs were poorly used by the respondents in their work. This might not be unconnected with the fact that it is a sophisticated and expensive device/technology.

\section{Radio}

Concerning the use of radio, the result in Table 4 shows that $66 \%$ of the respondents used it very often, $17 \%$ used it often, $7 \%$ used it rarely and $10 \%$ did not at all. Thus, this finding agrees with other studies that asserted the usage of ICT. For example, [11] exemplified a typical ICT usage project involving extension workers and farmers in the Pacific in terms of ability to produce DVDs, printed guides, radio and TV Programmes in strengthening rural economies. It also agrees with report by [13] on Africa posited that radio was a dominant medium of mass communication and describing radio as a community source of information.

This shows that radio sets were highly used by the respondents in their work as a means of communication in the performance of their work. Consequently, with radio they were adequately informed about agricultural information and could be assisted more effectively in delivering extension messages through it.

In summary, the results of the calculated weighted means indicate that the respondents agreed that, in their extent of ICT usage, had the following weighted mean scores: GSM phones (3.65), radio (3.38), cassette recorder (2.66) and television (2.65), respectively. These figures were obviously equal to or above the expected weighted average of 2.5. This indicates that these ICT components (i.e. GSM phones, radio, cassette recorder and television) were greatly used by the respondents in their work. However, the results on the calculated weighted means of other selected ICT components were below the expected weighted mean, namely: landline phones, cinema, CD/DVD player, VHS Video player, camera, internet, and computer. Others were: overhead projector, fax, and PDAs.

Table 4. Distribution of the respondents according to extent of ICT usage for their work.

\begin{tabular}{|c|c|c|c|c|c|c|c|}
\hline \multirow[b]{2}{*}{ S/No } & \multirow[b]{2}{*}{ ICT Component } & \multicolumn{4}{|c|}{ Extent of ICT Usage for work } & \multirow[b]{2}{*}{$\begin{array}{l}\text { Weighted } \\
\text { sum }\end{array}$} & \multirow[b]{2}{*}{$\begin{array}{l}\text { Weighted } \\
\text { mean }(\pi)\end{array}$} \\
\hline & & Very often (F) & Often $(F)$ & Rarely (F) & Not at all (F) & & \\
\hline 1 & GSM phones & $153(75)$ & $34(16.7)$ & $13(6.4)$ & $4(2.0)$ & 744 & $3.65^{*}$ \\
\hline 2 & Radio & $134(65.7)$ & $34(16.7)$ & $15(7.4)$ & $21(10.3)$ & 689 & $3.38 *$ \\
\hline 3 & Cassette recorder & $65(31.9)$ & $56(27.5)$ & $31(15.2)$ & $52(25.5)$ & 542 & $2.66^{*}$ \\
\hline 4 & Television set & $65(31.9)$ & $49(24.0)$ & $44(21.6)$ & $46(22.5)$ & 541 & $2.65 *$ \\
\hline 5 & Land line phones & $12(5.9)$ & $44(21.1)$ & $42(20.6)$ & $106(52.5)$ & 310 & 1.52 \\
\hline 7 & CD/DVD player & $33(16.2)$ & $59(28.9)$ & $44(21.6)$ & $68(33.3)$ & 426 & 2.10 \\
\hline 8 & VHS Video player & $33(16.2)$ & $54(26.5)$ & $44(21.6)$ & $73(35.8)$ & 455 & 2.23 \\
\hline 9 & Camera & $21(10.3)$ & $38(18.6)$ & $76(37.3)$ & $69(33.8)$ & 409 & 2.01 \\
\hline 10 & Internet (e-mailing) & $4(2.0)$ & $21(10.3)$ & $70(34.3)$ & $109(53.4)$ & 302 & 1.48 \\
\hline 11 & Computer & $10(4.9)$ & $28(13.7)$ & $68(33.3)$ & $98(48.0)$ & 358 & 1.76 \\
\hline 12 & Overhead projector & $1(0.5)$ & $14(6.9)$ & $59(28.9)$ & $130(63.7)$ & 294 & 1.44 \\
\hline 13 & Fax & $3(1.5)$ & $3(1.5)$ & $25(12.3)$ & $173(84.8)$ & 244 & 1.20 \\
\hline 14 & Pocket devices (PDAs) & $10(4.9)$ & $16(7.8)$ & $35(17.2)$ & $143(70.1)$ & 301 & 1.48 \\
\hline
\end{tabular}

* =ICT components with high weighted means

Note: Figures in parenthesis are percentages $(\%)$.

\section{Conclusion}

The level of awareness of ICTs among the respondents
(VEAs) was quite high especially on radio (99\%), GSM phones (96\%); and television (93\%). On the contrary, the level of awareness was low on fax $(68 \%)$ and Personal Digital Assistant (PDAs) (69\%). The extent of Usage of ICT 
by the respondents in their work was remarkably high on the following devices; GSM phones, radio, cassette recorder, television, CD/DVD player and VHS video player. This indicates the VEAs had some considerable opportunity to use them.

\section{Recommendations}

The following recommendations are derived from the study;

The level of awareness of the respondents on ICT was found to be high, hence, it is recommended that awareness of these ICT platforms be intensified among the VEAs by their employers and the governments so as to enhance their usage.

On the extent of usage of ICT by the respondents for their work, they recorded least ICT usage on fax and pocket PDAs and cinema. It is recommended therefore that fax, cinema and PDAs should be encouraged for use more frequently in order to bring more awareness and accessibility of respective VEAs in existing ADPs.

\section{References}

[1] Aderinto, A., Adedoyin, S. F., Awotide, D. O. and Adamu, C. O. (2008). Use ofInformation and Communication Technologies (ICTs) Among Extension Personnel in Ondo State. Nigerian Journal of Rural Sociology, 8 (1), 66-70.

[2] Adesope, O. M. and E. Matthews-Njoku (2005). Perceived Effect of Information Technology on Agricultural Research among Agriculturists in Nigerian Tertiary Institutions. In: Proceedings of Agricultural Extension Society of Nigeria (AESON) $10^{\text {th }}$ Annual Conference, Ilorin, Nigeria, (10), 96101.

[3] Apantanku, S. O. and Lawal-Adebowale, O. A. (2009). ICT Status of Agricultural Research and Extension Organizations in South-Western Nigeria: Policy Implications for ICT-Based Information Exchanges. Journal of AppliedAgriculturalResearch, (1), 3-12.

[4] Atala, T. and M. M. Umar (2006). AnEvaluation of global system of mobile communication (GSM) use in newsgathering and reporting in Kaduna, Nigeria. The Nigerian Journal of Communications, 4 (Nos 1\&2), 149-155.

[5] Buskens, I. and Webb, A. (2009). AfricanWomen \& ICTs: Investigating Technology, Gender, and Empowerment. IDRC/UNISA/Zed Books, 22p.

[6] Chete, F. O., Udi, H. O. and Osubor, V. I. (2008). Evaluation of Delta State E-Government Website. The Information Technologist, 5 (2): 80-90.

[7] Contreras. (1980). Brazil and Guatemala: Communications, Rural Modernity and Structural Constraints. In: McAnany, E. G. (Ed.): Communications in the Rural Third World. PreagerPublishers, U.S.A., pp. 72-78.

[8] Eisenstadt, S. N. (1973). Tradition, Change and Modernity. John Wiley and Sons, New York, U. S. A., 362p.
[9] Jibowo, A. A. (2005). History of Agricultural Extension in Nigeria. In: Agricultural Extension in Nigeria: S. F. Adedoyin (ed.). Agricultural Extension Society of Nigeria (AESON), Ilorin, Nigeria, pp 1-12.

[10] Leeuwis, C. and van den Ban, A. W. (2004). Communication for Rural Innovation: Rethinking Agricultural Extension (Third Edition). Blackwell Publishing Ltd., United Kingdom, pp. 412 .

[11] Masianini, B. and Rokotuibau, M. (2009). Case Study: Listening to Farmers. In: ICT Update (Issue No 49) June, p1011. Also available online at: http://ictupdate.cta.int/.

[12] Matthews-Njoku, E. C. (2003). Farmers' personal and farm enterprise characteristicsand their adoption of improved cassavaproduction technologies in Imo State, Nigeria. Journal of Agriculture and Social Research 3 (1): 90-104.

[13] Mayers, M. (2008). Radio and Development in Africa: A Concept Paper. Prepared for the International Development Research Centre (IDRC) of Canada. Updated Report in March, 2009. Available and accessed online at: www.research4development.info/projectsandprogrammes.asp and www.idrc.ca/en/ev-148305-201-1-DO_TOPIC.html.

[14] Moore, E. W. (1963). Modernization: Social Change. PrenticeHall, Inc., Eaglewood Cliffs, New Jersey, U. S. A, pp. 89-97.

[15] Murtala, N., Jibril, S. A., Haruna, U. and Atumeyi, G. A. (2007). Role of Information and Communication in the adoption of new technologies by farmers in Jos-South Local Government Area, Plateau State. Proceedings of the $12^{\text {th }}$ National Conference of AESON, 4- ${ }^{\text {th }}$ July, Pp38-45: Maiduguri, Nigeria.

[16] Omotayo, O. M. (2005). ICT andAgricultural Extension: Emerging Issues in Transferring Agricultural Technology in Developing Countries. In: S. FolaAdedoyin (Ed), Agricultural Extension in Nigeria. Agricultural Extension Society of Nigeria (AESON), Ilorin, Nigeria, pp145-158.

[17] Rogers, M. E. and Burdges, J. R. (1972). Social Change in Rural Societies (Second Edition). Prentice-Hall, Inc., Eaglewood Cliffs, New Jersey, U. S. A., 445p.

[18] Sennuga, S. O., Angba, A. O. and Fadiji, T. O. (2020). Adoption of Appropriate Good Agricultural Practices (GAPs) Technologies among Smallholder Farmers in Nigeria. International Journal of Agricultural Research, Sustainability and Food Sufficiency 7 (02): 447-458.

[19] Wikipedia (2010a). ICT in Agriculture. Accessed online in March 2010 at: http://en.wikipedia.org/wiki/ICT_in_Agriculture/

[20] Voh, J. P. (1981). Information sources and awareness of selected recommended farm practices: A study in a village in Kaduna State of Nigeria. African Journal of Agricultural Sciences, 8 (1 \& 2): 77-87.

[21] Yazidu, I. (1973). The study of Radio as a means of communicating Agricultural Information to Farmers in Northern States of Nigeria. Unpublished M. Sc. Thesis, submitted to the Department of Agricultural Economics and Rural Sociology, Ahmadu Bello University, Zaria. 